\title{
Improvement of Science Learning Outcomes Through the Problem Based Learning (PBL) Model for Grade 4 Elementary School Students
}

\section{Dyah Puriwati Rahayu}

SD Negeri 1 Sokaraja Wetan

rahayudiah002@gmail.com

\section{Article History}

accepted 01/11/2020

approved 08/11/2020

published 15/11/2020

\begin{abstract}
This study aims to improve student learning outcomes in science material The Impact of Uncontrolled Utilization of Natural Resources in everyday life through Problem Based Learning. This research is a classroom action research conducted in three cycles. Each cycle consists of four stages, namely planning, implementing, observing, and reflecting. The research was conducted on the fourth grade students of SD Negeri 1 Sokaraja Wetan with a total of 15 students. This research was conducted at SDN 1 Sokaraja Wetan, Sokaraja District, Banyumas Regency. The research was conducted from October to November 2020. The results of the study showed that student learning outcomes in science materials had an increase in the impact of uncontrolled use of natural resources in everyday life. This can be seen from the average value of learning outcomes in cycle I of 62, increasing to 78 in cycle II. And in cycle III the average value rose to 78.7 . The number of students who completed the first cycle was $47 \%$, in the second cycle it increased to $87 \%$ and in the third cycle it became $93 \%$. So it can be concluded that using the Problem Based Learning learning model can improve the learning outcomes of fourth grade students of SD Negeri 1 Sokaraja Wetan in science material The Impact of Uncontrolled Utilization of Natural Resources in Daily Life.
\end{abstract}

Keywords: Problem based learning, learning outcomes, science

\begin{abstract}
Abstrak
Penelitian ini bertujuan untuk meningkatkan hasil belajar siswa dalam materi IPA Dampak Pemanfaatan Sumber Daya Alam yang Tidak Terkontrol Dalam kehidupan Sehari - hari melalui Problem Based Learning. Penelitian ini merupakan penelitian tindakan kelas yang dilakukan sebanyak tiga siklus. Tiap siklus terdiri dari empat tahapan yaitu perencanaan, pelaksanaan, obsevasi, dan refleksi. Penelitian dilaksanakan pada siswa kelas IV SD Negeri 1 Sokaraja Wetan dengan jumlah 15 siswa. Penelitian ini dilaksanakan di SD Negeri SDN 1 Sokaraja Wetan Kecamatan Sokaraja Kabupaten Banyumas. Waktu Penelitian dilaksanakan pada bulan Oktober sampai November 2020. Hasil penelitian menunujukan bahwa hasil belajar siswa dalam materi IPA Dampak Pemanfaatan Sumber Daya Alam Yang Tidak terkontrol Dalam Kehidupan Sehari - hari mengalami peningkatan. Hal ini dapat dilihat dari nilai rata-rata hasil belajar pada siklus I sebesar 62 naik menjadi 78 pada siklus II. Dan pada siklus III nilai ratarata naik menjadi 78,7 . Jumlah siswa yang tuntas pada siklus I yaitu $47 \%$, pada siklus II naik menjadi $87 \%$ dan pada siklus III menjadi $93 \%$. Jadi dapat disimpulkan dengan menggunakan model Pembelajaran Problem Based Learning dapat meningkatkan hasil belajar siswa kelas IV SD Negeri 1 Sokaraja Wetan dalam materi IPA Dampak Pemanfaatan Sumber Daya Alam Yang tidak Terkontrol dalam kehidupan Sehari - hari.
\end{abstract}

Kata kunci: Problem based learning, Hasil belajar, IPA

Social, Humanities, and Education Studies (SHEs): Conference Series https://jurnal.uns.ac.id/shes 


\section{PENDAHULUAN}

Pembelajaran adalah suatu usaha yang disengaja, bertujuan, dan terkendali agar orang lain belajar atau terjadi perubahan yang relatif menetap pada diri orang lain, Miarso dalam Rusmono (2012: 6). Didalam proses pembelajaran terdapat peran peserta didik sebagai subyek belajar. Aktifitas belajar peserta didik tidak hanya sekedar mendengar dan mencatat materi pembelajaran yang diberikan oleh guru. Dalam hal ini peserta didik harus diberikan peran aktif serta dijadikan mitra dalam proses pembelajaran sehingga peserta didik bertindak sebagai peserta didik yang aktif. Suasana dan kondisi belajar yang menyenangkan, dimana tercipta interaksi yang baik antara guru dan peserta didik maupun peserta didik dengan peserta didik akan sangat membantu dan mendukung peserta didik dalam mendapatkan pengalaman belajar. Peserta didik akan lebih mudah dalam menguasai materi yang dipelajari dan pembelajaran akan lebih bermakna bagi peserta didik. Dalam hal ini guru mempunyai tugas untuk memilih model pembelajaran yang sesuai dengan jenis materi yang akan disampaikan demi tercapainya tujuan pembelajaran.

Sukarno dalam Wisudawati dan Sulistiyowati (2017: 23) IPA berarti ilmu yang mempelajari tentang sebab dan akibat kejadian- kejadian yang ada di alam ini. IImu Pengetahuan Alam (IPA) merupakan salah satu disiplin ilmu yang didalamnya mengkaji berbagai kajian ilmu alam diantaranya fisika, kimia dan biologi. Mata pelajaran IPA ini sangat penting kedudukannya dalam masyarakat karena IPA membahas mengenai makhluk hidup, proses kehidupan, alam serta peristiwa alam yang erat kaitannya dengan kehidupan sehari- hari. Tidak memungkiri jika mata pelajaran IPA menjadi mata pelajaran wajib mulai dari sekolah tingkat dasar (SD/ MI) hingga sekolah menengah atas (SMA/ MA). Namun selama ini masih banyak peserta didik yang mengalami kesulitan dalam memahami dan mengikuti pelajaran ini. Tidak sedikit dari mereka beranggapan bahwa mata pelajaran IPA itu membosankan dikarenakan terlalu banyak cakupan materi yang harus mereka pelajari.

Keberhasilan pembelajaran IPA dapat dilihat dari kreativitas guru menggunakan model pembelajaran yang diterapkan dalam mengajar mata pelajaran IPA yang tepat dan menarik. Suasana belajar yang kondusif terjadi interaksi yang baik antara guru dengan peserta didik maupun peserta didik dengan peserta didik, sehingga tercapai tujuan pembelajaran. Model pembelajaran pada dasarnya merupakan bentuk pembelajaran yang tergambar dari awal sampai akhir yang disajikan secara khas oleh guru, Sutirman (2013: 22) Model pembelajaran merupakan alternatif yang digunakan oleh guru untuk mensiasati dalam kegiatan menstranfer ilmu pengetahuan agar mudah diterima oleh peserta didik, sehingga pembelajaran menjadi bermakna. Model pembelajaran dapat dipilih oleh guru dengan memperhatikan karakteristik materi pembelajaran serta kondisi peserta didik. Salah satu model pembelajaran yang dapat diterapkan dalam pembelajaran IPA adalah model pembelajaran Problem Based Learning (PBL).

Berdasarkan observasi yang telah dilakukan di SDN 1 Sokaraja Wetan ditemukan permasalahan bahwa hasil belajar peserta didik pada mata pelajaran IPA masih rendah. Hal ini terbukti melalui Diperoleh hasil ulangan yang menunjukkan bahwa masih banyak peserta didik yang mendapatkan nilai ulangan harian pelajaran IPA materi pokok Dampak Pemanfaatan Sumber Daya Alam yang Tidak Terkontrol Dalam Kehidupan Sehari - hari masih di bawah Kriteria Ketuntasan Minimum (KKM) dengan nilai standar KKM 65, tuntas belajar 33\% (5 peserta didik) tuntas belajar, sedangkan sebanyak $67 \%$ (10 peserta didik) belum tuntas belajar. Berdasarkan permasalahan tersebut peneliti mengamati bahwa rendahnya hasil belajar mata pelajaran IPA dikarenakan peserta didik kurang fokus dalam memperhatikan penjelasan dari guru, banyak peserta didik yang sibuk sendiri ketika pembelajaran berlangsung. Selain itu 
pada saat proses pembelajaran peserta didik kurang berperan aktif dan dominan guru yang berperan aktif dikelas (teacher center), sehingga kegiatan mereka hanya mendengarkan materi yang di sampaikan oleh guru yang akhirnya menimbulkan kejenuhan.

Berdasarkan data guru yang diperoleh dari hasil evaluasi peserta didik yang menunjukkan bahwa masih banyak peserta didik yang mendapatkan nilai ulangan pada pembelajaran IPA materi pokok Dampak Pemanfaatan Sumber Daya Alam yang Tidak Terkontrol Dalam Kehidupan Sehari - hari masih di bawah Kriteria Ketuntasan Minimum (KKM) dengan nilai standar KKM 65, tuntas belajar 33\% (5 peserta didik) tuntas belajar, sedangkan sebanyak 67\% (10 peserta didik) belum tuntas belajar.yang mendapat nilai di bawah KKM.

Permasalahan di atas membutuhkan usaha pemecahan masalah agar peserta didik termotivasi dalam proses pembelajaran dan tujuan pembelajaran tercapai sehingga prestasi belajar peserta didik meningkat. Maka untuk mengatasi permasalahan tersebut perlu adanya penggunaan media pembelajaran yang dapat menarik minat belajar peserta didik sehingga peserta didik terangsang dalam melakukan proses pembelajaran, sehingga hasil belajar peserta didik dapat meningkat.

IPA

Menurut Sukarno dalam Wisudawati dan Sulistiyowati (2017: 23) IPA berarti ilmu yang mempelajari tentang sebab dan akibat kejadian- kejadian yang ada di alam ini.

Menurut Susanto (2013: 167) Sains atau IPA adalah usaha manusia dalam memahami alam semesta melalui pengamatan yang tepat pada sasaran, serta menggunakan prosedur , dan dijelaskan dengan penalaran sehingga mendapatkan suatu kesimpulan. Dari kedua pendapat tersebut dapat disimpulkan bahwa IImu Pengetahuan Alam (IPA) adalah ilmu yang mempelajari tentang alam semesta baik akibat serta kejadiankejadian yang ada di alam.

Dalam bukunya Ahmad Susanto (2013: 168) menjelaskan hakikat IPA adalah sebagai berikut:

a. IPA sebagai produk

IPA sebagai produk yaitu kumpulan hasil penelitian yang telah ilmuan lakukan dan sudah membentuk konsep yang telah dikaji sebgai kegiatan empiris dan kegiatan analitis.

b.IPA sebagai proses

IPA sebagai proses yaitu untuk menggali dan memahami pengetahuan tentang alam.

c.IPA sebagai sikap

IPA sebagai sikap yaitu sikap ilmiah harus dikembangkan dalam pembelajarn sains, hal ini sesuai dengan sikap yang harus dimiliki oleh seorang ilmuan dalam melakukan penelitian dan mengomunikasikan penelitian.

Dari uraian di atas dapat disimpulkan bahwa hakikat IImu Pengetahuan Alam (IPA) dibagi menjadi tiga yaitu IPA sebagai produk, IPA sebagai proses dan juga IPA sebagai sikap.

IImu Pengetahuan Alam (IPA) memiliki karakteristik sebagai dasar untuk memahaminya. Jacobson \& Bergman dalam Susanto 2013: 170) berpendapat bahwa karakteristik pembelajaran IPA meliputi:

a. IPA merupakan kumpulan konsep- konsep, prinsip- prinsip, hukum dan teori;

b. Proses ilmiah dapat berupa fisik dan mental serta mencerminkan fenomena alam, termasuk juga penerapannya;

c. Sikap keteguhan hati, keingintahuan dan ketekunan dalam menyingkap rahasia alam; 
d. IPA tidak dapat membuktikan semua, akan tetapi hanya sebagian atau beberapa saja.

Dari uraian karakteristik di atas dapat disimpulkan bahwa IImu Pengetahuan Alam (IPA) memiliki karakteristik sebagai dasar untuk memahaminya serta pembeda dari mata pelajaran yang lain.

Tujuan pembelajaran IPA di Sekolah Dasar (SD)/ Madarasah Ibtidaiyah (MI) dalam Badan Nasional Standar Pendidikan dalam Susanto (2013: 171-172) yaitu:

a. Memperoleh keyakinan terhadap kebesaran Tuhan Yang Maha Esa berdasarkan keberadaan, keindahan, dan keteraturan alam cipta-Nya.

b. Mengembangkan pengetahuan dan pemahaman konsep- konsep IPA yang bermanfaat dan dapat diterapkan dalam kehidupan sehari- hari.

c. Mengembangkan rasa ingin tahu, sikap positif dan kesadaran tentang adanya hubungan yang saling mempengaruhi antara IPA, lingkungan, teknologi dan masyarakat.

d. Mengembangkan ketrampilan proses untuk menyelidiki alam sekitar memecahkan masalah, dan membuat keputusan.

e. Meningkatkan kesadaran untuk berperan serta dalam memelihara, menjaga, dan melestarikan lingkungan alam.

f. Meningkatkan kesadaran untuk menghargai alam Dan segala keteraturannya sebagai salah satu ciptaan Tuhan.

g. Memperoleh bekal pengetahuan, konsep, dan keterampilan IPA sebagai dasar untuk melanjutkan pendidikan ke SMP.

Ruang lingkupbahan kajian IPA untuk Sekolah Dasar (SD)/ Madarasah Ibtidaiyah (MI) meliputi aspek- aspek berikut:

1. Makhluk hidup dan proses kehidupan, yaitu manusia, hewan, tumbuhan dan interaksinya dengan lingkungan serta kesehatan.

2. Benda/ materi, sifat- sifat dan kegunaannya meliputi: cair, padat, dan gas.

3. Energi dan perubahannya meliputi: gaya, bunyi, panas, magnet, listrik, cahaya, dan pesawat sederhana.

4. Bumi dan alam semesta, meliputi: tanah, bumi, tata surya, dan benda- benda langit lainnya (Peraturan Menteri Pendidikan No. 22 Tahun 2006: 485).

Sumber daya adalah sesuatu yang memiliki nilai guna. Sumber Daya Alam (SDA) adalah keseluruhan faktor fisik, kimia, biologi dan sosial yang membentuk lingkungan sekitar kita.

Sumber daya alam (SDA) merupakan rahmat karunia Tuhan YME yang harus dikelola secara baik dan benar agar dapat memberikan manfaat kepada rnanusia secara maksimal dan lestari. Pembangunan bertujuan untuk meningkatkan kesejahteraan manusia dengan mengembangkan dan memanfaatkan SDA yang ada. Dalam pemanfaatan SDA melalui pembangunan senantiasa terjadi perubahan ekosistem yang pada akhirnya memberi dampak positif (manfaat) ataupun dampak negatif (resiko) terhadap manusia kembali. Semakin besar manfaat yang akan diupayakan, semakin besar pula resiko yang ada ataupun muncul resiko baru. [3]

Pengelolaan SDA (natural resource management) dimaksud untuk mempertahankan dan meningkatkan kualitas lingkungan yang tinggi, aman dan manusiawi terjamin. Hanya dalam kondisi kualitas lingkungan yang tinggi, manusia lebih banyak memperoleh manfaat dari pada resiko lingkungan. Secara lebih spesifik pengertian pengelolaan SDA meliputi dua hal sebagai berikut:

1. Usaha manusia dalam mengubah ekosistem SDA agar dapat diperoleh manfaat yang maksimal dan berkesinambungan. 
2. Proses pengalokasian SDA dalam ruang dan waktu untuk memenuhi kebutuhan manusia dengan senantiasa mengupayakan

a) Pertimbangan antara populasi manusia dan sumberdaya.

b) Pencegahan kerusakan sumberdaya alam (dan lingkungan).

. Definisi Problem Based Learning (PBL)

Menurut Ridwan (2015 : 127) Problem Based Learning (PBL) merupakan pembelajaran yang penyampainnya dilakukan dengan cara menyajikan suatu permasalahan, mengajukan pertanyaan- pertanyaan, memfasilitasi penyelidikan, dan membuka dialog.

Menurut Duch dalam Aris Shoimin (2014: 130) menyatakan bahwa Problem Based Learning (PBL) atau Pembelajaran Berbasis Masalah (PBM) adalah model pengajaran yang bercirikan permasalahan nyata sebagai konteks untuk para peserta didik belajar berpikir kritis dan keterampilan memecahkan masalah serta memperoleh pengetahuan.

Menurut Finkle dan Top dalam Aris Shoimin (2014: 130) menyatakan bahwa PBM merupakan pengembangan kurikulum dan sistem pengajaran yang mengembangkan secara stimultan strategi pemecahan masalah dan dasar- dasar pengetahuan dan ketrampilan dengan menempatkan peserta didik dalam peran aktif sebagai pemecahan masalah sehari- hari yang terstruktur dengan baik.

Dari pendapat diatas dapat disimpulkan bahwa model Problem Based Learning (PBL) merupakan model pembelajaran yang bercirikan suasana pembelajaran yang diarahkan oleh suatu permasalahan sehari- hari sebagai konteks peserta didik dalam berpikir kritis dalam memecahkan suatu masalah serta memperoleh pengetahuan. Permasalahan dalam model pembelajaran ini dapat diajukan dari guru kepada peserta didik, dari peserta didik kepada guru atau dari peserta didik itu sendiri, yang kemudian dijadikan pembahasan dan dicari pemecahannya sebagai kegiatan- kegiatan belajar peserta didik.

Penggunaan model ini memiliki tujuan agar peserta didik dapat memberdayakan, mengasah, menguji dan mengembangkan kemampuan berfikirnya secara berkesinambungan. Serta peserta didik didorong untuk dapat mengembangkan pengetahuannya sendiri.

Dengan demikian, dengan model ini diharapkan peserta didik dapat:

a. Menyelesaikan masalah dengan seluruh pengetahuan dan ketrampilan mereka dari berbagai sumber yang dapat diperoleh.

b. Memberdayakan, mengasah, menguji dan mengembangkan kemampuan berfikirnya secara berkesinambungan.

Dari uraian di atas dapat disimpulkan bahwa, tujuan model Problem Based Learning (PBL) adalah mengasah kemampuan berfikir peserta didik dalam memecahkan masalah. Hal ini agar peserta didik membuktikan sendiri materi yang sedang dipelajarinya sesuai atau tidak dengan teori yang ada dan terlatihnya peserta didik dalam berfikir ilmiah (Najma, 2017: 29-30).

\section{Langkah- langkah Problem Based Learning (PBL)}

Sintaks atau langkah- langkah pembelajaran Problem Based Learning (PBL) dalam Sani (2012: 157) yaitu pada tabel 2.1 sebagai berikut:

Tabel 2. 1 Langkah- langkah model PBL 


\begin{tabular}{|c|c|c|}
\hline No. & Fase & \multicolumn{1}{c|}{ Kegiatan Guru } \\
\hline $\mathbf{1}$ & $\begin{array}{l}\text { Memberikan orientasi } \\
\text { permasalahan kepada } \\
\text { peserta didik }\end{array}$ & $\begin{array}{l}\text { Menyajikan permasalahan,membahas tujuan } \\
\text { pembelajaran, memaparkan kebutuhan logistik untuk } \\
\text { pembelajaran, memotivasi peserta didik untuk } \\
\text { terlibat aktif }\end{array}$ \\
\hline $\mathbf{2}$ & $\begin{array}{l}\text { Mengorganisasikan } \\
\text { peserta didik untuk } \\
\text { penyelidikan }\end{array}$ & $\begin{array}{l}\text { Membantu peserta didik dalam mendefinisikan dan } \\
\text { mengorganisasikan tugas belajar/penyelidikan untuk } \\
\text { menyelesaikan permasalahan }\end{array}$ \\
\hline $\mathbf{3}$ & $\begin{array}{l}\text { Pelaksanaan investigasi } \\
\mathbf{4}\end{array}$ & $\begin{array}{l}\text { Mendorong peserta didik untuk memperoleh } \\
\text { informasi yang tepat, melaksanakan } \\
\text { penyelidikan,penjelasan solusi }\end{array}$ \\
\hline $\mathbf{5 .}$ & $\begin{array}{l}\text { Mengembangkan } \\
\text { menyajikan hasil }\end{array}$ & $\begin{array}{l}\text { Membantu peserta didik merencanakan produk yang } \\
\text { tepat dan relevan, seperti laporan, rekaman vidio, dan } \\
\text { sebagainya untuk keperluan penyampaian hasil }\end{array}$ \\
\hline
\end{tabular}

Menurut Aris Shoimin (2014: 132) ada 8 kelebihan model pembelajaran PBL yaitu sebagai berikut:

1) Peserta didik didorong untuk memiliki kemampuan memecahkan masalah dalam situasi nyata.

2) Peserta didik memiliki kemampuan membangun pengetahuannya sendiri melalui aktivitas belajar.

3) Pembelajaran berfokus pada masalah sehingga materi yang tidak ada hubungannya tidak perlu dipelajari oleh peserta didik Hal ini mengurangi beban peserta didik dengan menghafal atau menyimpan informasi.

4) Terjadi aktivitas ilmiah pada peserta didik melalui kerja kelompok.

5) Peserta didik terbiasa menggunakan sumber- sumber pengetahuan baik dari perpustakaan, internet, wawancara, dan observasi.

6) Peserta didik memiliki kemampuan menilai kemajuan belajarnya sendiri.

7) Peserta didik memiliki kemampuan untuk melakukan komunikasi ilmiah dalam kegiatan diskusi atau presentasi hasil pekerjaan mereka.

8) Kesulitan belajar peserta didik secara individu dapat diatasi melalui kerja kelompok dalam bentuk peer teaching.

Berdasarkan uraian di atas, maka rumusan masalah pada penelitian ini adalah bagaimana model problem based learning (PBL) untuk meningkatkan hasil belajar materi IPA materi Dampak Pemanfaatan Sumber Daya Alam yang Tidak Terkontrol dalam Kehidupan Sehari- hari pada peserta didik kelas IV B SD Negeri1 Sokaraja Wetan tahun pelajaran 2020/2021?

Tujuan dari penelitian ini adalah mendeskripsikan penggunaan model Pembelajaran Problem Based Learning (PBL) untuk meningkatkan hasil belajar materi IPA Dampak Pemanfaatan Sumber Daya Alam Yang Tidak terkontrol Dalam kehidupan 
Sehari - hari pada peserta didik kelas IV SD Negeri 1 Sokaraja Wetan tahun pelajaran 2020/2021.

\section{METODE}

Penelitian ini merupakan penelitian tindakan kelas yang dilaksanakan dalam tiga siklus. Setiap siklus terdiri dari tahap perencanaan, pelaksanaan, observasi dan refleksi. Subjek penelitian ini adalah siswa kelas IV SD Negeri 1 Sokaraja Wetan Tahun 2020/2021 yang berjumlah 15 anak.

Teknik pengumpulan data yang di gunakan dalam penelitian ini adalah tes yang digunakan untuk mendapatkan data tentang hasil belajar siswa. Instrumen pengumpulan data yang digunakan dalam penelitian ini adalah butir soal evaluasi. Analisis data yang di gunakan dalam penelitian ini adalah analisis deskriptif komparatif untuk membandingkan hasil belajar melalui tes formatif/nilai ulangan harian antar siklus.

\section{Penerapan}

\section{HASIL DAN PEMBAHASAN}

Model pembelajaran yang digunakan dalam pembelajaran IPA materi Dampak Pemanfaatan Lingkungan yang tidak terkontrol sehari - hari adalah model Problem Based Learning.. Siswa diminta untuk mengamati slide powerpoint dan video yang ditampilkan oleh peneliti. Siswa diharapkan dapat menganalisis, membuat prediksi dan dapat menyajikan laporan kegiatan upaya pelestarian lingkungan yang dilakukan.Kegiatan Pendahuluan diisi dengan memberi salam, menanyakan kabar, berdoa, mengabsen siswa, menyanyikan lagu Nasional, dan menyampaikan tujuan pembelajaran. Kegiatan inti diisi dengan mengamati slide powerpoint dan video Dampak Pemanfaatan Sumber Daya Alam yang tidak terkontrol Dalam kehidupan sehari - hari, kemudian mengidentifikasi, menggali informasi dan membuat prediksi yang akan terjadi pada kenampakan hutan pada tahun 2030 serta menyajikan laporan kegiatan upaya pelestarian lingkungan. Pada kegiatan penutup diisi dengan penguatan, kesimpulan, dan penilaian.

\section{Hasil Belajar}

Hasil penelitian yang dilakukan pada siklus I sampai III menunjukan adanya peningkatan hasil belajar dalam materi IPA Dampak Pemanfaatan Sumber Daya Alam Yang Tidak Terkontrol Dalam Kehidupan sehari - hari. Peningkatan hasil belajar tersebut terlihat pada gambar di bawah ini. 
SHEs: Conference Series 3 (3) (2020) 83-92

Gambar 1. Peningkatan hasil belajar

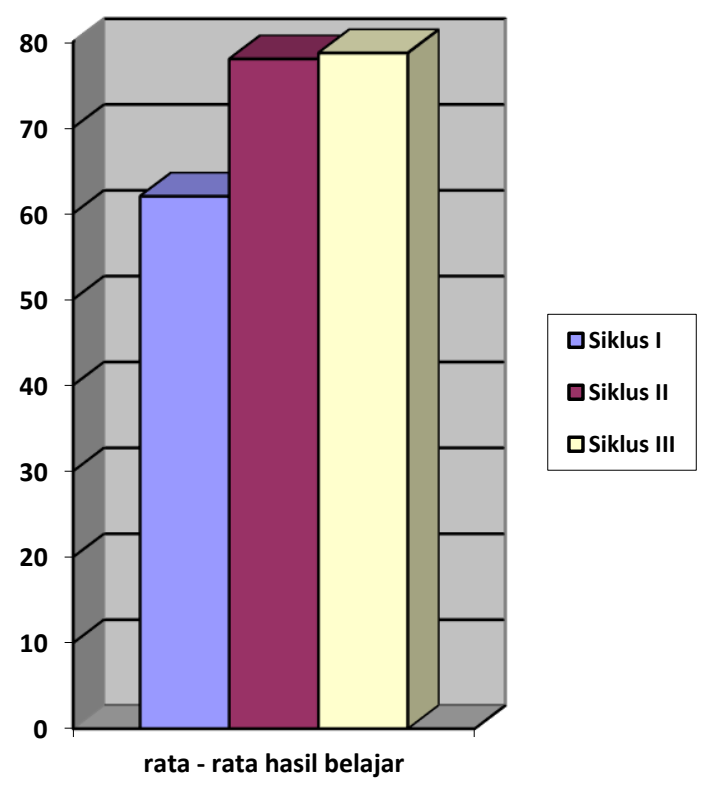

\section{Gambar 1. Rata-rata hasil belajar}

Berdasarkan gambar di atas dapat terlihat adanya peningkatan rata-rata hasil belajar pada tiap siklusnya. Pada siklus pertama rata-rata hasil belajar siswa meningkat menjadi 62. Selanjutnya pada siklus II rata-rata hasil belajar siswa meningkat menjadi 78 dan meningkat lagi menjadi 78,7 pada siklus III.

Selain peningkatan hasil belajar, ketuntasan belajar pada tiap siklus juga mengalami peningkatan. Peningkatan ketuntasan belajar dapat dilihat pada gambar di bawah ini.

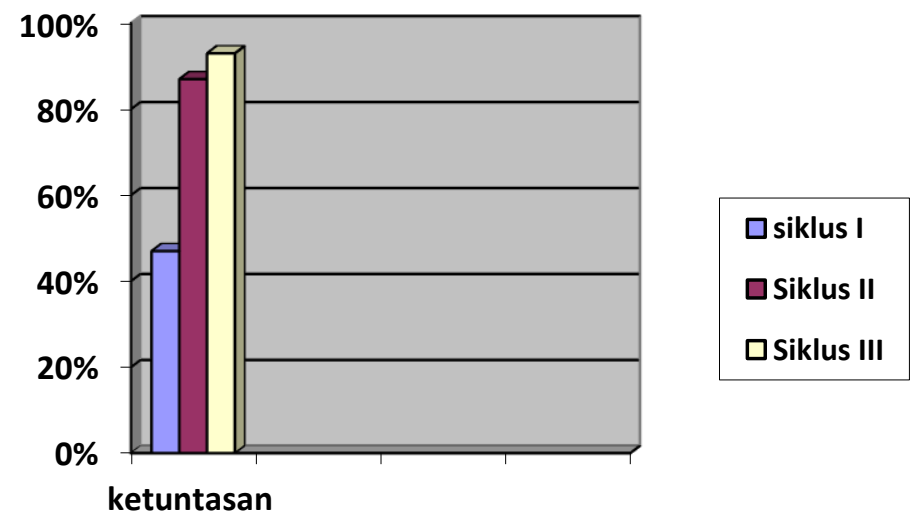

Gambar 2. Persentase ketuntasan belajar 
Berdasarkan gambar tersebut dapat terlihat adanya peningkatan ketuntasan hasil belajar pada tiap siklusnya.pada siklus I ketuntasan belajar siswa dalam materi IPA Dampak Pemanfaatan Sumber Daya Alam Yang Tidak Terkontrol Dalam Kehidupan Sehari - hari sebanyak $47 \%$ dan siklus II meningkat menjadi $87 \%$. Pada siklus III ketuntasan belajar meningkat lagi menjadi 93\%.

Berdasarkan analisis di atas dapat disimpulkan bahwa kegiatan pembelajaran menggunakan model problem Based Learning dapat meningkatkan hasil belajar siswa dalam materi IPA Pemanfaatan Sumber Daya Alam Yang Tidak terkontrol Dalam Kehidupan sehari - hari . Secara umum PBL sangat mempengaruhi suasana belajar menjadi lebih menyenangkan. Kegiatan pembelajaran menggunakan Problem Based L Learning mampu menarik perhatian dan membuat siswa lebih fokus pada pembelajaran, sehingga hasil belajar siswa pun meningkat.

Peningkatan hasil belajar tersebut sesuai dengan hasil penelitian yang dilakukan oleh bahwa penerapan Problem Based Learning terbukti dapat meningkatkan hasil belajar IPA.

\section{SIMPULAN}

Berdasarkan hasil penelitian yang dilakukan pada siklus 1, 2, dan 3 dapat disimpulkan bahwa penerapan Problem Based Learning dapat meningkatkan hasil belajar siswa dalam IPA Materi Sumber Daya Alam yang tidak terkontrol dalam kehidupan sehari - hari yang ditandai dengan peningkatan persentase ketuntasan belajar siklus $147 \%$ dengan rata-rata hasil belajar 62 . Kemudian meningkat pada siklus 2 persentase ketuntasan belajar menjadi $87 \%$ dengan rata-rata hasil belajar menjadi 78. Pada siklus 3 terjadi peningkatan lagi dengan persentase ketuntasan belajar 93\% dan rata-rata hasil belajar menjadi 78,7.

Berdasarkan kesimpulan penelitian, maka dapat disarankan beberapa hal sebagai berikut: (1)Guru dapat menggunakan Problem Based Learning sebagai model pembelajaran agar siswa lebih tertarik dalam pembelajaran sehingga hasil belajar meningkat, (2) Guru dapat meningkatkan kemampuan profesionalnya dengan menerapkan model pembelajaran Problem Based Learning dalam kegiatan pembelajaran.

\section{DAFTAR PUSTAKA}

F Nuraini. 2017.Penggunaan Model Problem Based Learning(PBL) Untuk Meningkatkan Hasil Belajar IPA Kelas 5 SD http://www.ejurnalmitrapendidikan.com/index.php/e-jmp/article/view/82jurnalmitrapendidikan.com

Rusmono. 2012. Strategi Pembelajaran Problem Based Learning. Jakarta: Ghalia Indonesia

R.Rahmasari.2016.Penerapan Model Pembelajaran Problem Based Learning Untuk Meningkatkan Hasil Belajar IPA Kelas IV http://journal.student.uny.ac.id/ojs/ojs/index.php/pgsd/article/view/5367. journal.student.uny.ac.id.

Sani, Ridwan Abdullah. 2015. Pembelajaran Saintifik Untuk Implementasi Kurikulum 2013. Jakarta: Bumi Aksara.

Shoimin, Aris. 2014. 68 Model Pembelajaran Inovatif dalam Kurikulum 2013. Yogyakarta: Ar- Ruzz Media.

Susanto, Ahmad. 2013. Teori Belajar Pembelajaran di Sekolah Dasar. Jakarta : PT Kharisma Putra Utama. 
SHEs: Conference Series 3 (3) (2020) 83-92

Sutirman. 2013. Media \& Model- model Pembelajaran Inovatif. Yogyakarta : Graha IImu.

Wisudawati, Widi dan Sulistiyowati, Eka. 2017. Metodologi Pembelajaran IPA.Jakarta : Bumi Aksara. 